\title{
Dancing cheek to cheek: Cryptococcus neoformans and phagocytes
}

\author{
Mingshun Zhang ${ }^{1,2}$, Donglei Sun ${ }^{1}$ and Meiqing Shi ${ }^{*}$
}

\begin{abstract}
Meningoencephalitis caused by Cryptococcus neoformans ( $\mathrm{Cn}$ ) has become one of the leading causes of mortality in AIDS patients. Understanding the interactions between $\mathrm{Cn}$ and phagocytes is fundamental in exploring the pathogenicity of cryptococcal meningoencephalitis. Cn may be extracellular or contained in the monocytes, macrophages, neutrophils, dendritic cells and even endothelial cells. The internalized Cn may proliferate inside the host cells, or cause the lysis of host cells, or leave the host cells via non-lytic exocytosis, or even hijack the host cells (Trojan horse) for the brain dissemination, which are regulated by microbe factors and also immune molecules. Coexistence of protective and deleterious roles of phagocytes in the progression of cryptococcosis warrant further investigation.
\end{abstract}

Keywords: Cryptococcus neoformans, Macrophage, Neutrophil, Dendritic cell, Endothelial cell

\section{Background}

$\mathrm{Cn}$ has been co-evolved with the phagocyte predators, e.g., amoebas (Chrisman et al. 2010), paramecium (Frager et al. 2010), or nematodes (Casadevall et al. 2003), for a long history. As mammalian phagocytes may originate from the common ancestors, it is plausible to speculate that roles of host phagocytes against $\mathrm{Cn}$ manifest the complex interactions between fungi and phagocyte predators (Chrisman et al. 2010). Ideally, predators and their prey fight with each other and maintain the fine balance of nature, implying that neither the prey $(\mathrm{Cn})$ nor the predators (e.g., amoeba, or host phagocytes) would be totally extinguished. Therefore, in the host both $\mathrm{Cn}$ and phagocytes would survive, leading to a latent infection, as evidenced by the recent research (Alanio et al. 2015).

Cryptococcal meningoencephalitis occurs only when $\mathrm{Cn}$ leaves the infected lung, transmigrates across the blood-brain-barrier (BBB) and proliferates in the brain parenchyma. As $\mathrm{Cn}$ is a facultative intracellular pathogen, it is speculated that the transmigrating $\mathrm{Cn}$ might be extracellular or within some phagocytes, thereby

\footnotetext{
*Correspondence: mshi@umd.edu

${ }^{1}$ Division of Immunology, Virginia-Maryland Regional College of Veterinary Medicine, University of Maryland, College Park, MD, USA Full list of author information is available at the end of the article
}

invading the central nervous system (CNS) via a transcellular pathway or Trojan horse pathway (Casadevall 2010). In the trans-cellular pathway, $\mathrm{Cn}$ is directly internalized by brain endothelial cells via endocytosis. In the Trojan horse pathway, some phagocytes carrying $\mathrm{Cn}$ enter the CNS. High-affinity Fc $\gamma$ receptor 3A promotes the phagocytosis and significantly contributes to the cryptococcal meningoencephalitis (Rohatgi et al. 2013). Moreover, effective phagocytosis of $\mathrm{Cn}$ by macrophages counterintuitively predisposes to poor outcome (Sabiiti et al. 2014), confirming the link between phagocytosis of $\mathrm{Cn}$ and the high mortality in patients with cryptococcal meningoencephalitis (Alanio et al. 2011). Together, these data suggest that phagocytes may help $\mathrm{Cn}$ invade the CNS. In this review, the interactions between $\mathrm{Cn}$ and phagocytes (monocytes, macrophages, neutrophils, dendritic cells, and endothelial cells) are discussed.

\section{Monocytes and macrophages}

Circulating $\mathrm{Cn}$ could be detected in monocytes collected from peripheral blood or located in monocytes in the leptomeningeal capillaries. Besides, $\mathrm{Cn}$ also could be observed in macrophages in the leptomeningeal space, implying that monocytes and macrophages may play crucial roles in the pathogenesis of cryptococcal meningoencephalitis (Chretien et al. 2002). The outcomes of Cn

\section{望 Springer}

(C) 2015 Zhang et al. This article is distributed under the terms of the Creative Commons Attribution 4.0 International License (http://creativecommons.org/licenses/by/4.0/), which permits unrestricted use, distribution, and reproduction in any medium, provided you give appropriate credit to the original author(s) and the source, provide a link to the Creative Commons license, and indicate if changes were made. 
interacting with macrophages include at least phagocytosis, replication, and non-lytic exocytosis (Coelho et al. 2014; Garcia-Rodas and Zaragoza 2012; Leopold Wager and Wormley 2014; McQuiston and Williamson 2012), implicating the existence of Trojan horse pathway for the brain dissemination (Casadevall 2010; Charlier et al. 2009) (Fig. 1).

\section{Phagocytosis}

Phagocytosis of $\mathrm{Cn}$ by macrophages is mediated by diverse factors, including complement proteins, specific antibodies, surfactant protein D (Geunes-Boyer et al. 2009, 2012) or the scavenger receptors SCARF1 and CD36 (Means et al. 2009). IgM and IgA specific to the capsular glucuronoxylomannan (GXM) promote complement-independent and CD18-dependent phagocytosis (Taborda and Casadevall 2002). Phagocytosis of $\mathrm{Cn}$ by lung macrophages is significantly impaired in the sIgM deficient mice (Subramaniam et al. 2010). Different from IgG1, IgM and IgA, IgG3-mediated phagocytosis is not associated with Fc $\gamma \mathrm{R}$ and CD18 (Saylor et al. 2010). In contrast, antiphagocytic protein 1 (App1) from $\mathrm{Cn}$, binding with CR2/CR3, inhibits the phagocytosis of macrophages (Stano et al. 2009; Williams and Del Poeta 2011).

\section{Replication}

As a facultative intracellular pathogen, $\mathrm{Cn}$ replicates in and alkalifies the phagosome of macrophages, leading to phagosome breakage and macrophage lysis (Tucker and Casadevall 2002). Replication of $\mathrm{Cn}$ inside the macrophages requires F-box protein 1 and its substrate inositol phosphosphingo lipid-phospholipase C1 (Liu and Xue 2014). In addition, Cn phospholipase B1 (PLB1) promotes the survival of fungi in the macrophages by facilitating fungal eicosanoid production (Noverr et al. 2003). In addition, $\mathrm{Cn}$ proliferation may stimulate the abortive mitosis (Coelho et al. 2012) of some macrophages (Luo et al. 2005). Mechanisms behind the balance of $\mathrm{Cn}$ replication and macrophage lysis/mitosis, however, still remain elusive. Interestingly, a recent study on the dynamics of interactions between $\mathrm{Cn}$ and macrophages suggested that fungal background influences outcome during cryptococcal meningoencephalitis in humans (Alanio et al. 2011).

\section{Non-lytic exocytosis}

Besides breaking down the host macrophage, $\mathrm{Cn}$ could also escape from macrophages through non-lytic exocytosis or phagosome extrusion in vitro (Alvarez and Casadevall 2006; Ma et al. 2006) or in vivo (Nicola et al.

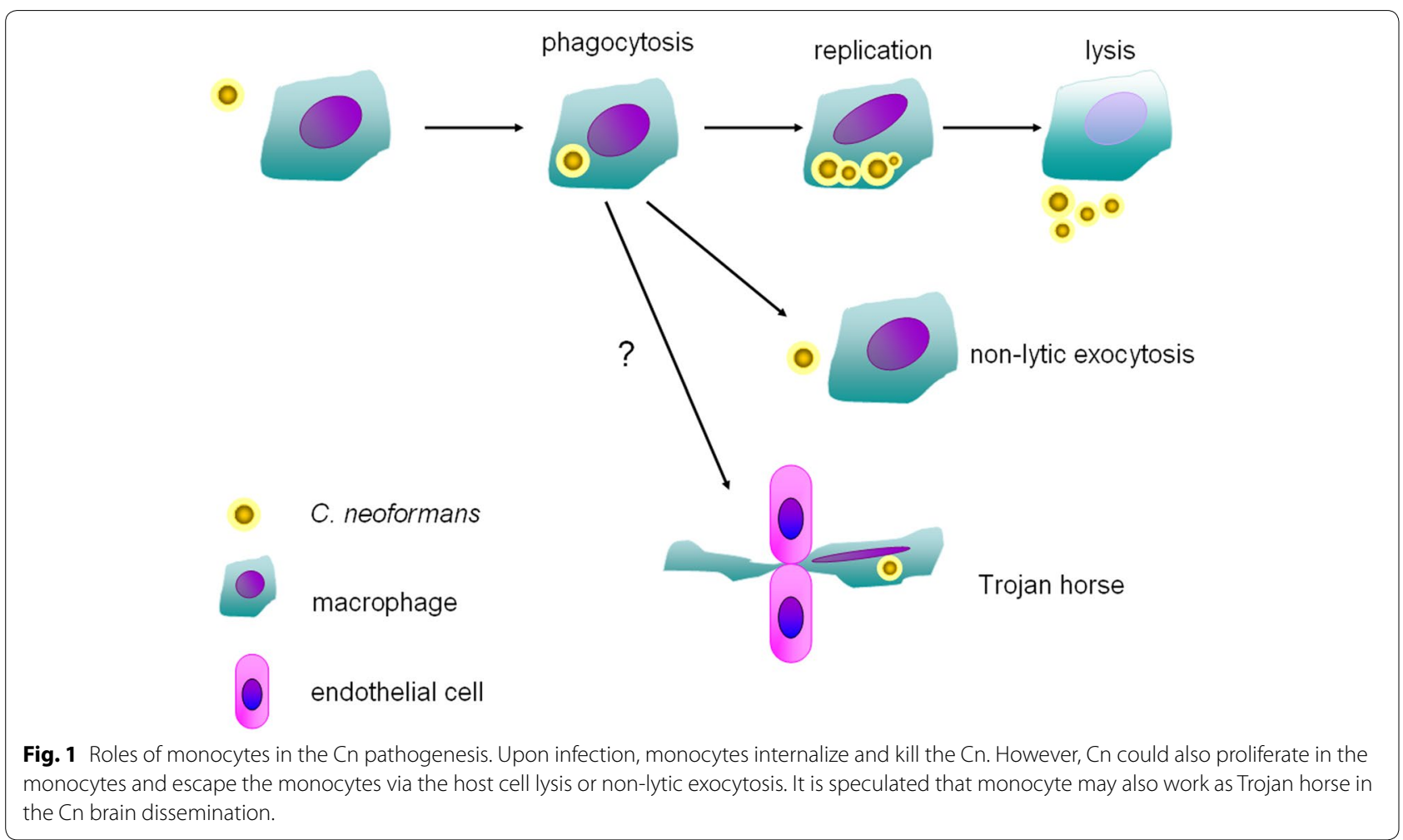


2011). Virulence factors from fungi, for example, secreted PLB1 and SEC14, are essential for non-lytic exocytosis (Chayakulkeeree et al. 2011). Host factors also regulate the non-lytic exocytosis. The addition of the weak bases ammonium chloride and chloroquine resulted in a significant increase of non-lytic exocytosis events, whereas the vacuolar ATPase inhibitor bafilomycin A1 had the opposite effect (Nicola et al. 2011). Interestingly, both phagosomal maturation dependent (Alvarez and Casadevall 2006) and independent (Ma et al. 2006) pathways have been reported for non-lytic exocytosis of $\mathrm{Cn}$ by macrophages. Arp $2 / 3$ complex-mediated actin polymerization has been show to inhibit non-lytic exocytosis (Johnston and May 2010). Antibody or complement, which mediates the phagocytosis, affects the outcome (Alvarez et al. 2008) but not the occurrence of non-lytic exocytosis (Alvarez and Casadevall 2006; Ma et al. 2006). Interestingly, autophagy knockdown increases the nonlytic exocytosis of $\mathrm{Cn}$ by macrophages (Nicola et al. 2012). Th1 and Th17 cytokines decrease the non-lytic exocytosis, while Th2 cytokines augment the extrusion of Cn out of macrophages (Voelz et al. 2009), which may contribute to the extravasation of $\mathrm{Cn}$ and the aggravation of the disease.

\section{Trojan horse}

It has been well documented that monocytes could transmigrate across the $\mathrm{BBB}$ and differentiate into perivascular macrophages. Thereby, it is tempting to hypothesize that monocyte harboring $\mathrm{Cn}$ might function as Trojan horse in the $\mathrm{Cn}$ brain dissemination. Phagocytosis of $\mathrm{Cn}$ inhibits the chemotaxis of macrophages stimulated by CX3CL1 and CSF-1 (Luo et al. 2009), which might slow down the crawling of macrophages containing $\mathrm{Cn}$ along the brain vasculature and therefore facilitate $\mathrm{Cn}$ transmigration. More compelling evidence for Trojan horse comes from the deliberate experiment showing that brain fungal burdens following injection with $\mathrm{Cn}$ internalized by macrophages, compared with free $\mathrm{Cn}$ inoculation, are significantly higher (Charlier et al. 2009). However, many issues for Trojan horse in $\mathrm{Cn}$ brain dissemination, including a direct observation rather the evaluation based on fungus quantification, and the mechanisms behind, still remain unresolved.

\section{Neutrophils}

It has been historically recognized that neutrophils have the ability to kill the $\mathrm{Cn}$, participating in the first-line defenses before a cell-mediated immune response develops (Diamond et al. 1972; Lehrer and Ladra 1977). In vitro, neutrophil kills $\mathrm{Cn}$ effectively especially combined with granulocyte colony-stimulating factor (G-CSF) or granulocyte-macrophage colony stimulating factor
(GM-CSF) (Chiller et al. 2002). In the murine model of cryptococcosis, G-CSF, if combined with fluconazole, is associated with the increased survival, suggesting that neutrophils contribute to host defenses in cryptococcal meningoencephalitis (Graybill et al. 1997). Administration of G-CSF into the AIDS patients increases the fungicidal activity and decreases the risk of infection (Vecchiarelli et al. 1995), which is associated with the enhanced leukotrienes from neutrophils upon G-CSF therapy (Coffey et al. 1998). In contrast, cryptococcosis is not usually associated with human neutropenia or with conditions characterized by defective neutrophil function (Casadevall and Perfect 1998), reflecting the complexity of roles of neutrophils against $\mathrm{Cn}$. We hypothesize the blurring effects of neutrophils are due to the co-existing protective (positive) and deleterious (negative) roles from neutrophils in the $\mathrm{Cn}$ pathogenesis.

$\mathrm{Cn}$ or the capsular polysaccharide glucuronoxylomannan (GXM) promotes the inflammatory cytokines (Retini et al. 1996) and chemokines (Lipovsky et al. 1998), thus displaying chemotactic activity on the neutrophils (Dong and Murphy 1993, 1995a). Paradoxically, GXM inhibits neutrophil migration or infiltration (Dong and Murphy 1995b), partially by reducing the L-selectin (Dong and Murphy 1996), E-selectin (Ellerbroek et al. 2002), IL-8 receptor (Lipovsky et al. 1998) of the neutrophils via cross-desensitization, or competitively binding with CD14 (Ellerbroek et al. 2004b), TLR4 (Ellerbroek et al. 2004b), CD18 (Dong and Murphy 1997) on the neutrophils. O-acetylation of GXM is a crucial motive for the inhibition of neutrophil recruitment (Ellerbroek et al. 2004a). Nevertheless, inoculation of Cn intravenously recruits neutrophils accumulated in pulmonary vessels, which is dependent on the complement 5a (C5a) (Lovchik and Lipscomb 1993). Neutrophils recruitment into the lung is also observed at the early phase (Abe et al. 2000; Feldmesser et al. 2000; Herring et al. 2005; Kawakami et al. 1999; Mednick et al. 2003) of Cn airway infection, although it might not be as evident as mononuclear cells in the mice infected with low-virulence strain (Feldmesser et al. 2000; Huffnagle et al. 1998). Recruitment of neutrophils into the lung is dependent on the chemokines including IL-8 (Guillot et al. 2008), MIP-2 and KC (Kawakami et al. 1999), which are elevated upon $\mathrm{Cn}$ infection. Cn could also negatively regulate the influx of neutrophils into the lung (O'Meara et al. 2013), deliberately reflecting the paradoxically dual roles in the interaction between neutrophils and $\mathrm{Cn}$.

The recruited neutrophils in the lung internalize $\mathrm{Cn}$ after intratracheal inoculation (Feldmesser et al. 2000), which is mediated by complement 3 (C3) (Kozel et al. 1984). Neutrophils activation enhances the phagocytosis (Kozel et al. 1987); while capsule of $\mathrm{Cn}$ inhibits the 
phagocytosis by neutrophils (Richardson et al. 1993). Cn is a facultative intracellular pathogen in the macrophages (Feldmesser et al. 2000). It is largely unknown the definite fate of $\mathrm{Cn}$ ingested by neutrophils. Although speculatively $\mathrm{Cn}$ might be protected in the neutrophils (Mednick et al. 2003), most research focused on the killing of $\mathrm{Cn}$ (Miller and Mitchell 1991), which might happen intracellularly or extracellularly (Qureshi et al. 2010, 2011), in a oxidative-dependent or oxidative-independent manner (Qu and Wang 1991). Myeloperoxidase (MPO) is a neutrophil-specific enzyme closely associated with reactiveoxygen species. MPO-deficient mice infected with $\mathrm{Cn}$ intranasally or intravenously survive significantly shorter, due to the impaired clearance of fungus in the lung and the spleen (Aratani et al. 2006). Inhibition of sphingomyelin synthase (SMS) also profoundly impairs the ability of neutrophils to kill $\mathrm{Cn}$, which are independent of phagocytosis (Qureshi et al. 2010).

Neutrophils are not only phagocytes but also the modulators of immune responses. Depletion of neutrophils results in a Th2 response and renders mice susceptible to Candida albicans infection (Romani et al. 1997). However, roles of neutrophil depletion on the infection of $\mathrm{Cn}$ are more complicated. Mice infected with $\mathrm{Cn}$ intratracheally survive significantly longer if neutrophils are transiently depleted $24 \mathrm{~h}$ before the fungus inoculation, which is associated with the higher levels of IL-10, TNF- $\alpha$, IL-4 and IL-12 in the lung (Mednick et al. 2003).
In contrast to the protective role of neutrophil depletion, mice defective in neutrophil-specific enzyme MPO are hyper-susceptible to $\mathrm{Cn}$, which might result from higher level of IL-4 and reduced production of IL-12, IFN- $\gamma$ in the lung (Aratani et al. 2006). To add complexity more, neutrophil depletion in the mice infected with Cn expressing IFN- $\gamma$ results in increased IL-17A production from $\gamma \delta \mathrm{T}$ cells, but has no role on the fungus burden (Wozniak et al. 2012) (Fig. 2).

\section{Dendritic cells}

Upon Cn airway infection, CCR2 mediates the recruitment of Ly6G ${ }^{\text {high }}$ monocytes (Osterholzer et al. 2009a), which differentiate into dendritic cells (DCs) and contribute to the Th1 response (Osterholzer et al. 2008). As the most potent antigen presenting cells, DCs internalize $\mathrm{Cn}$ via mannose receptor and Fc $\gamma \mathrm{R}-\mathrm{II}$ in vitro (Syme et al. 2002) and in vivo (Wozniak et al. 2006), which is partially inhibited by the capsule (Vecchiarelli et al. 2003). In contrast, mannoproteins, interacting with CD206 and CD209 (Mansour et al. 2006), promote the maturation of dendritic cells (Pietrella et al. 2005). In the CD206 deficient mice, maturation of dendritic cells upon mannoproteins, however, is not hampered (Dan et al. 2008). Complements and specific antibodies promote the phagocytosis of Cn by dendritic cells (Kelly et al. 2005). Following phagocytosis, DCs kill the intracellular Cn via the fusion of endosome and lysosome and present

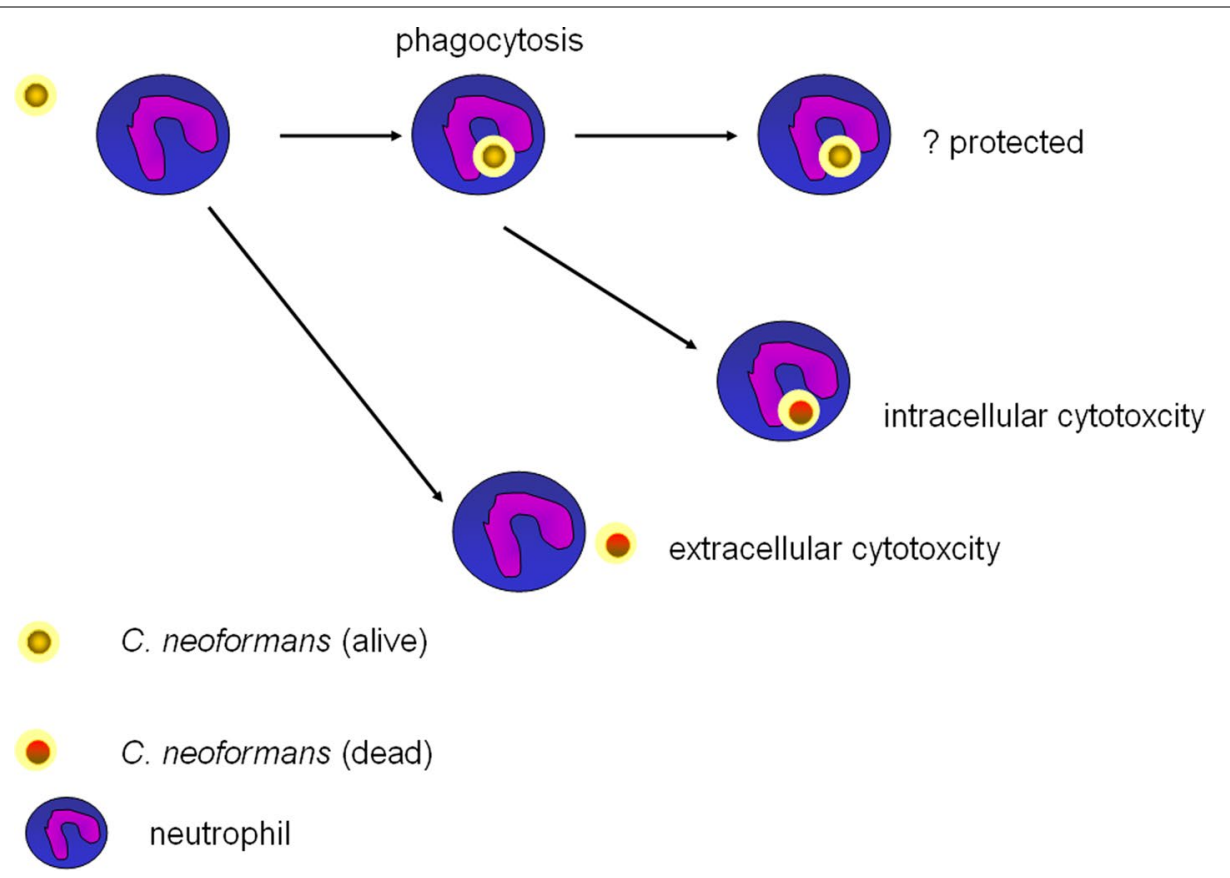

Fig. 2 Roles of neutrophils in the Cn pathogenesis. Neutrophil could kill Cn extracellularly or intracellularly. Meanwhile, limited evidences argue that neutrophil may also protect the internalized $\mathrm{Cn}$. 
antigens to T cells (Wozniak and Levitz 2008). The direct cytotoxicity of DCs against $\mathrm{Cn}$ is further confirmed in a recent study showing that purified lysosomal enzymes, specifically cathepsin B, inhibit cryptococcal growth in vitro (Hole et al. 2012).

In the lymphnodes, Langerhans cells and myeloid DC induce protective $\mathrm{CD} 4^{+} \mathrm{T}$ cell responses against $\mathrm{Cn}$ (Bauman et al. 2000), which is augmented by TNF- $\alpha$ (Bauman et al. 2003). Accordingly, TNF- $\alpha$ deficiency decreases mature dendritic cell trafficking and produces a chronic Cn infection (Herring et al. 2005). Compared with myeloid DCs, plasmacytoid DCs induce non-protective immune response against $\mathrm{Cn}$ (Bauman et al. 2000; Siegemund and Alber 2008). Besides, non-protective Th2 responses could also be induced by immature dendritic cells in the lung, which are promoted by $\mathrm{Cn}$ urease (Osterholzer et al. 2009b) (Fig. 3).

\section{Endothelial cells}

Different from monocytes/macrophages, neutrophils and dendritic cells, endothelial cells are not professional phagocytes. Yet, $\mathrm{Cn}$ is observed in the brain endothelial cells of infected mice (Chretien et al. 2002). In vitro, free $\mathrm{Cn}$ could be surrounded by microvillus-like membrane protrusions and subsequently internalized by brain endothelial cells (Chang et al. 2004). Multiple molecules are engaged in the interactions between endothelial cells and extracellular $\mathrm{Cn}$. Hyaluronic acid (HA) from $\mathrm{Cn}$ is the ligand of CD44 on the endothelial cells (Jong et al. 2008). In the process of transcellular migration, CD44 is co-localized with phosphorylated caveolin-1, forming thread-like structure (Long et al. 2012) and promoting the lipid raft-dependent endocytosis (Huang et al. 2011). Fungal burden in the brain is significantly decreased in the CD44 deficient mice intravascularly infected with $\mathrm{Cn}$ (Jong et al. 2012). Besides HA-CD44 pathway, urease (Shi et al. 2010), plasmin (Stie and Fox 2012), or metalloprotease Mpr1 (Vu et al. 2014) promotes migration of $\mathrm{Cn}$ across the brain endothelium by facilitating attachment of cryptococci to the endothelial cells, which induces the cytoskeleton remodeling and internalization ( $\mathrm{Vu}$ et al. 2013). Of note, some other fungi, for example, Candida albicans also invades brain endothelial cells via endocytosis (Filler and Sheppard 2006). Thus, it would be interesting to explore whether or not brain endothelial cells express some unique receptors for $\mathrm{Cn}$. Although there is no evidence, it is hypothesized that the internalized $\mathrm{Cn}$ would be expulsed from endothelial cells into the brain neuropil. Mechanisms for the $\mathrm{Cn}$ exocytosis from the endothelial cells are largely unknown. Moreover, human brain endothelial cells (Filler and Sheppard 2006) but not human umbilical vein endothelial cells (Roseff and Levitz 1993) or mouse brain endothelial cells (Sabiiti

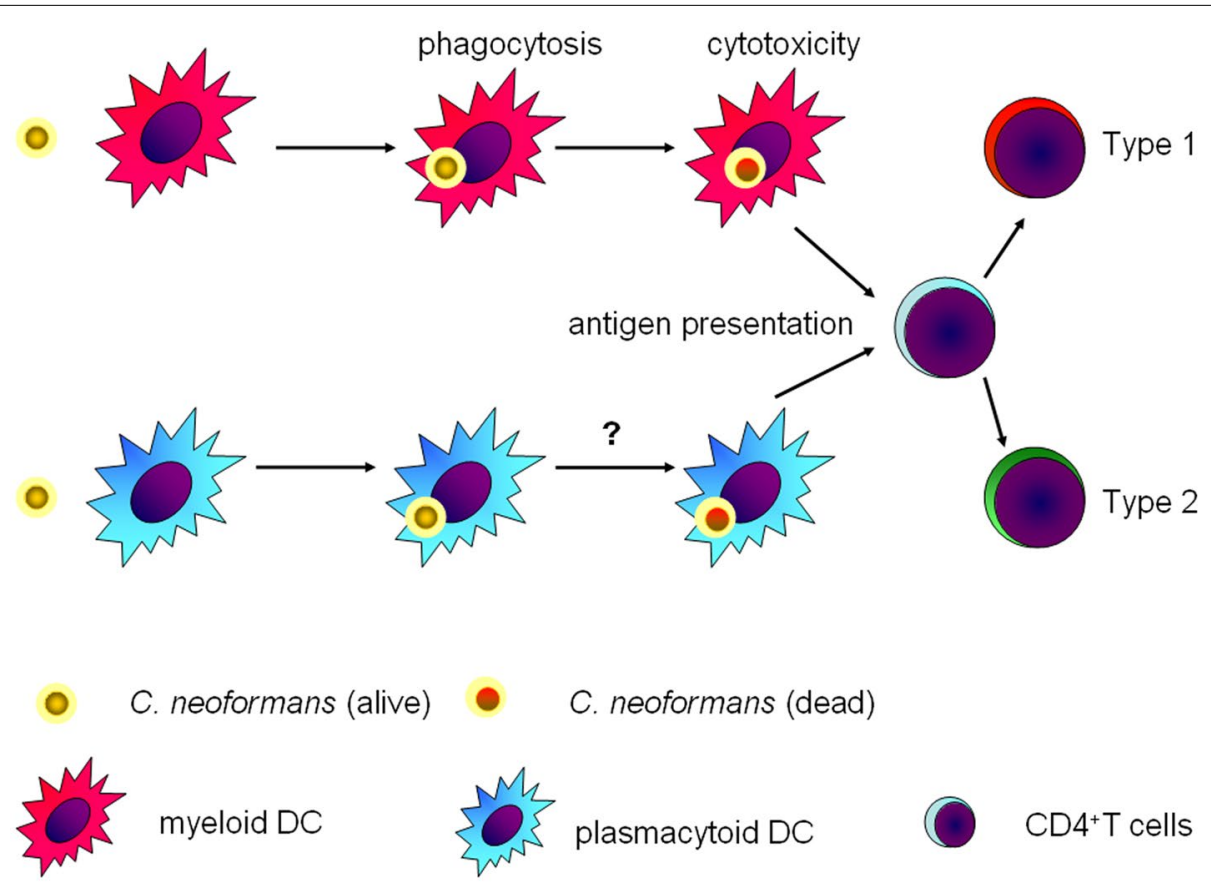

Fig. 3 Roles of dendritic cells in the Cn pathogenesis. As most powerful antigen presenting cells, myeloid dendritic cells process and present $\mathrm{Cn}$ antigen to $\mathrm{CD}^{+}{ }^{+} \mathrm{T}$ cells for the differentiation of cytotoxic Th1 cells. In contrast, plasmacytoid dendritic cells induce the non-protective Th2 cells. No evidence for the survival or death of $\mathrm{Cn}$ inside the plasmacytoid dendritic cells has been yet provided in the literature. 


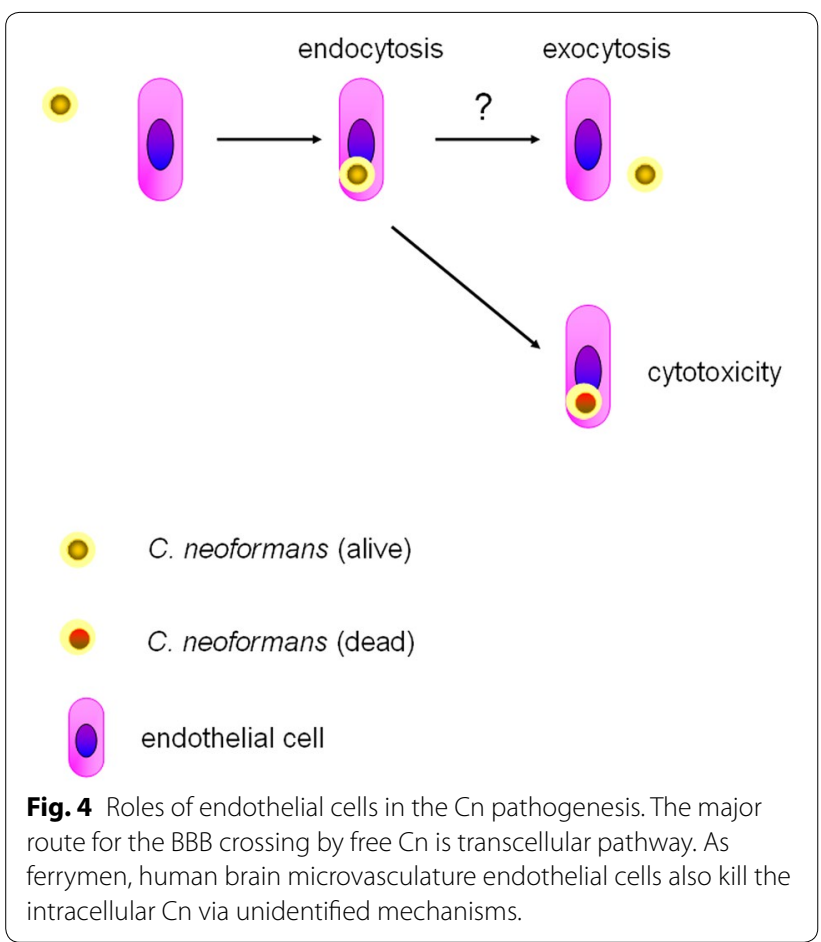

and May 2012) may also have the capability to kill the internalized Cn (Fig. 4).

\section{Conclusions}

Serological evidences suggest that people may have been infected with environmental $\mathrm{Cn}$ in early childhood (Goldman et al. 2001). Most of Cn infection might be asymptomatic unless the immune defense is significantly suppressed (e.g., organ transplant patients) or defective (e.g., AIDS patients). $\mathrm{Cn}$ is overwhelmingly distributed in the environment and may hide in the people with weakened immune system (Saha et al. 2007). However, only a fraction of organ transplant patients or AIDS patients would develop fatal cryptococcosis. Are there any unidentified factors breaking the fine balance between $\mathrm{Cn}$ and phagocytes in the lung or even in the brain? How do phagocytes dynamically interact with $\mathrm{Cn}$ in the brain vasculature? How do phagocytes containing $\mathrm{Cn}$ transmigrate to the brain parenchyma? How does the free $\mathrm{Cn}$ escape from the BBB endothelial cells? Obviously, roles of phagocytes in cryptococcosis deserve further investigation.

\section{Abbreviations}

Cn: Cryptococcus neoformans; BBB: blood-brain-barrier; CNS: central nervous system; App1: antiphagocytic protein 1; PLB1: phospholipase B1; G-CSF: granulocyte colony-stimulating factor; GXM: glucuronoxylomannan; C3: complement 3; MPO: myeloperoxidase; SMS: sphingomyelin synthase; DCs: dendritic cells; HA: hyaluronic acid.

\section{Authors' contributions}

MZ carried out the study and drafted the manuscript. DS participated in the design of the study. MS conceived of the study and helped to draft the manuscript. All authors read and approved the final manuscript.

\section{Author details}

${ }^{1}$ Division of Immunology, Virginia-Maryland Regional College of Veterinary Medicine, University of Maryland, College Park, MD, USA. ${ }^{2}$ Department of Immunology, Nanjing Medical University, Nanjing, Jiangsu, China.

\section{Acknowledgements}

This work was supported by the start-up funds from the University of Maryland (to MS) and key project of Nanjing Medical University (2014NJMUZD010, to $M Z)$.

\section{Compliance with ethical guidelines}

\section{Competing interests}

The authors declare that they have no competing interests.

\section{Ethical statement}

All of above research was approved by the ethics committee of the University of Maryland.

Received: 7 May 2015 Accepted: 29 July 2015

Published online: 12 August 2015

\section{References}

Abe K, Kadota J, Ishimatsu Y, Iwashita T, Tomono K, Kawakami K et al (2000) Th1-Th2 cytokine kinetics in the bronchoalveolar lavage fluid of mice infected with Cryptococcus neoformans of different virulences. Microbiol Immunol 44:849-855

Alanio A, Desnos-Ollivier M, Dromer F (2011) Dynamics of Cryptococcus neoformans-macrophage interactions reveal that fungal background influences outcome during cryptococcal meningoencephalitis in humans. MBio 2(4). doi:10.1128/mBio.00158-11

Alanio A, Vernel-Pauillac F, Sturny-Leclere A, Dromer F (2015) Cryptococcus neoformans host adaptation: toward biological evidence of dormancy. MBio 6(2). doi:10.1128/mBio.02580-14

Alvarez M, Casadevall A (2006) Phagosome extrusion and host-cell survival after Cryptococcus neoformans phagocytosis by macrophages. Curr Biol 16:2161-2165

Alvarez M, Saylor C, Casadevall A (2008) Antibody action after phagocytosis promotes Cryptococcus neoformans and Cryptococcus gattii macrophage exocytosis with biofilm-like microcolony formation. Cell Microbiol 10:1622-1633

Aratani Y, Kura F, Watanabe H, Akagawa H, Takano Y, Ishida-Okawara A et al (2006) Contribution of the myeloperoxidase-dependent oxidative system to host defence against Cryptococcus neoformans. J Med Microbiol 55:1291-1299

Bauman SK, Nichols KL, Murphy JW (2000) Dendritic cells in the induction of protective and nonprotective anticryptococcal cell-mediated immune responses. J Immunol 165:158-167

Bauman SK, Huffnagle GB, Murphy JW (2003) Effects of tumor necrosis factor alpha on dendritic cell accumulation in lymph nodes draining the immunization site and the impact on the anticryptococcal cell-mediated immune response. Infect Immun 71:68-74

Casadevall A (2010) Cryptococci at the brain gate: break and enter or use a Trojan horse? J Clin Invest 120:1389-1392

Casadevall A, Perfect JR (1998) Cryptococcus neoformans. American Society for Microbiology, Washington DC

Casadevall A, Steenbergen JN, Nosanchuk JD (2003) 'Ready made' virulence and 'dual use' virulence factors in pathogenic environmental fungi-the Cryptococcus neoformans paradigm. Curr Opin Microbiol 6:332-337

Chang YC, Stins MF, McCaffery MJ, Miller GF, Pare DR, Dam T et al (2004) Cryptococcal yeast cells invade the central nervous system via transcellular penetration of the blood-brain barrier. Infect Immun 72:4985-4995 
Charlier C, Nielsen K, Daou S, Brigitte M, Chretien F, Dromer F (2009) Evidence of a role for monocytes in dissemination and brain invasion by Cryptococcus neoformans. Infect Immun 77:120-127

Chayakulkeeree M, Johnston SA, Oei JB, Lev S, Williamson PR, Wilson CF et al (2011) SEC14 is a specific requirement for secretion of phospholipase B1 and pathogenicity of Cryptococcus neoformans. Mol Microbiol 80:1088-1101

Chiller T, Farrokhshad K, Brummer E, Stevens DA (2002) Effect of granulocyte colony-stimulating factor and granulocyte-macrophage colonystimulating factor on polymorphonuclear neutrophils, monocytes or monocyte-derived macrophages combined with voriconazole against Cryptococcus neoformans. Med Mycol 40:21-26

Chretien F, Lortholary O, Kansau I, Neuville S, Gray F, Dromer F (2002) Pathogenesis of cerebral Cryptococcus neoformans infection after fungemia. J Infect Dis 186:522-530

Chrisman CJ, Alvarez M, Casadevall A (2010) Phagocytosis of Cryptococcus neoformans by, and nonlytic exocytosis from, Acanthamoeba castellanii. Appl Environ Microbiol 76:6056-6062

Coelho C, Tesfa L, Zhang J, Rivera J, Goncalves T, Casadevall A (2012) Analysis of cell cycle and replication of mouse macrophages after in vivo and in vitro Cryptococcus neoformans infection using laser scanning cytometry. Infect Immun 80:1467-1478

Coelho C, Bocca AL, Casadevall A (2014) The intracellular life of Cryptococcus neoformans. Annu Rev Pathol 9:219-238

Coffey MJ, Phare SM, George S, Peters-Golden M, Kazanjian PH (1998) Granulocyte colony-stimulating factor administration to HIV-infected subjects augments reduced leukotriene synthesis and anticryptococcal activity in neutrophils. J Clin Invest 102:663-670

Dan JM, Kelly RM, Lee CK, Levitz SM (2008) Role of the mannose receptor in a murine model of Cryptococcus neoformans infection. Infect Immun 76:2362-2367

Diamond RD, Root RK, Bennett JE (1972) Factors influencing killing of Cryptococcus neoformans by human leukocytes in vitro. J Infect Dis 125:367-376

Dong ZM, Murphy JW (1993) Mobility of human neutrophils in response to Cryptococcus neoformans cells, culture filtrate antigen, and individual components of the antigen. Infect Immun 61:5067-5077

Dong ZM, Murphy JW (1995a) Effects of the two varieties of Cryptococcus neoformans cells and culture filtrate antigens on neutrophil locomotion. Infect Immun 63:2632-2644

Dong ZM, Murphy JW (1995b) Intravascular cryptococcal culture filtrate (CneF) and its major component, glucuronoxylomannan, are potent inhibitors of leukocyte accumulation. Infect Immun 63:770-778

Dong ZM, Murphy JW (1996) Cryptococcal polysaccharides induce L-selectin shedding and tumor necrosis factor receptor loss from the surface of human neutrophils. J Clin Invest 97:689-698

Dong ZM, Murphy JW (1997) Cryptococcal polysaccharides bind to CD18 on human neutrophils. Infect Immun 65:557-563

Ellerbroek PM, Hoepelman Al, Wolbers F, Zwaginga JJ, Coenjaerts FE (2002) Cryptococcal glucuronoxylomannan inhibits adhesion of neutrophils to stimulated endothelium in vitro by affecting both neutrophils and endothelial cells. Infect Immun 70:4762-4771

Ellerbroek PM, Lefeber DJ, van Veghel R, Scharringa J, Brouwer E, Gerwig GJ et al (2004a) O-acetylation of cryptococcal capsular glucuronoxylomannan is essential for interference with neutrophil migration. J Immunol 173:7513-7520

Ellerbroek PM, Ulfman LH, Hoepelman Al, Coenjaerts FE (2004b) Cryptococcal glucuronoxylomannan interferes with neutrophil rolling on the endothelium. Cell Microbiol 6:581-592

Feldmesser M, Kress Y, Novikoff P, Casadevall A (2000) Cryptococcus neoformans is a facultative intracellular pathogen in murine pulmonary infection. Infect Immun 68:4225-4237

Filler SG, Sheppard DC (2006) Fungal invasion of normally non-phagocytic host cells. PLoS Pathog 2:e129

Frager SZ, Chrisman CJ, Shakked R, Casadevall A (2010) Paramecium species ingest and kill the cells of the human pathogenic fungus Cryptococcus neoformans. Med Mycol 48:775-779

Garcia-Rodas R, Zaragoza O (2012) Catch me if you can: phagocytosis and killing avoidance by Cryptococcus neoformans. Fems Immunol Med Microbiol 64:147-161
Geunes-Boyer S, Oliver TN, Janbon G, Lodge JK, Heitman J, Perfect JR et al (2009) Surfactant protein D increases phagocytosis of hypocapsular Cryptococcus neoformans by murine macrophages and enhances fungal survival. Infect Immun 77:2783-2794

Geunes-Boyer S, Beers MF, Perfect JR, Heitman J, Wright JR (2012) Surfactant protein D facilitates Cryptococcus neoformans infection. Infect Immun 80:2444-2453

Goldman DL, Khine H, Abadi J, Lindenberg DJ, Pirofski L, Niang R et al (2001) Serologic evidence for Cryptococcus neoformans infection in early childhood. Pediatrics 107:E66

Graybill JR, Bocanegra R, Lambros C, Luther MF (1997) Granulocyte colony stimulating factor therapy of experimental cryptococcal meningitis. J Med Vet Mycol 35:243-247

Guillot L, Carroll SF, Badawy M, Qureshi ST (2008) Cryptococcus neoformans induces IL-8 secretion and CXCL1 expression by human bronchial epithelial cells. Respir Res 9:9

Herring AC, Falkowski NR, Chen GH, McDonald RA, Toews GB, Huffnagle GB (2005) Transient neutralization of tumor necrosis factor alpha can produce a chronic fungal infection in an immunocompetent host: potential role of immature dendritic cells. Infect Immun 73:39-49

Hole CR, Bui H, Wormley FL Jr, Wozniak KL (2012) Mechanisms of dendritic cell lysosomal killing of Cryptococcus. Sci Rep 2:739

Huang SH, Long M, Wu CH, Kwon-Chung KJ, Chang YC, Chi F et al (2011) Invasion of Cryptococcus neoformans into human brain microvascular endothelial cells is mediated through the lipid rafts-endocytic pathway via the dual specificity tyrosine phosphorylation-regulated kinase 3 (DYRK3). J Biol Chem 286:34761-34769

Huffnagle GB, Boyd MB, Street NE, Lipscomb MF (1998) IL-5 is required for eosinophil recruitment, crystal deposition, and mononuclear cell recruitment during a pulmonary Cryptococcus neoformans infection in genetically susceptible mice (C57BL/6). J Immunol 160:2393-2400

Johnston SA, May RC (2010) The human fungal pathogen Cryptococcus neoformans escapes macrophages by a phagosome emptying mechanism that is inhibited by Arp2/3 complex-mediated actin polymerisation. PLoS Pathog 6:e1001041

Jong A, Wu CH, Shackleford GM, Kwon-Chung KJ, Chang YC, Chen HM et al (2008) Involvement of human CD44 during Cryptococcus neoformans infection of brain microvascular endothelial cells. Cell Microbiol 10:1313-1326

Jong A, Wu CH, Gonzales-Gomez I, Kwon-Chung KJ, Chang YC, Tseng HK et al (2012) Hyaluronic acid receptor CD44 deficiency is associated with decreased Cryptococcus neoformans brain infection. J Biol Chem 287:15298-15306

Kawakami K, Shibuya K, Qureshi MH, Zhang T, Koguchi Y, Tohyama M et al (1999) Chemokine responses and accumulation of inflammatory cells in the lungs of mice infected with highly virulent Cryptococcus neoformans: effects of interleukin-12. FEMS Immunol Med Microbiol 25:391-402

Kelly RM, Chen J, Yauch LE, Levitz SM (2005) Opsonic requirements for dendritic cell-mediated responses to Cryptococcus neoformans. Infect Immun 73:592-598

Kozel TR, Highison B, Stratton CJ (1984) Localization on encapsulated Cryptococcus neoformans of serum components opsonic for phagocytosis by macrophages and neutrophils. Infect Immun 43:574-579

Kozel TR, Pfrommer GS, Redelman D (1987) Activated neutrophils exhibit enhanced phagocytosis of Cryptococcus neoformans opsonized with normal human serum. Clin Exp Immunol 70:238-246

Lehrer RI, Ladra KM (1977) Fungicidal components of mammalian granulocytes active against Cryptococcus neoformans. J Infect Dis 136:96-99

Leopold Wager CM, Wormley FL Jr (2014) Classical versus alternative macrophage activation: the Ying and the Yang in host defense against pulmonary fungal infections. Mucosal Immunol 7:1023-1035

Lipovsky MM, Gekker G, Hu S, Ehrlich LC, Hoepelman Al, Peterson PK (1998) Cryptococcal glucuronoxylomannan induces interleukin (IL)-8 production by human microglia but inhibits neutrophil migration toward IL-8. J Infect Dis 177:260-263

Liu TB, Xue C (2014) Fbp1-mediated ubiquitin-proteasome pathway controls Cryptococcus neoformans virulence by regulating fungal intracellular growth in macrophages. Infect Immun 82:557-568 
Long M, Huang SH, Wu CH, Shackleford GM, Jong A (2012) Lipid raft/caveolae signaling is required for Cryptococcus neoformans invasion into human brain microvascular endothelial cells. J Biomed Sci 19:19. doi:10.1186/1423-0127-19-19

Lovchik JA, Lipscomb MF (1993) Role for C5 and neutrophils in the pulmonary intravascular clearance of circulating Cryptococcus neoformans. Am J Respir Cell Mol Biol 9:617-627

Luo Y, Tucker SC, Casadevall A (2005) FC- and complement-receptor activation stimulates cell cycle progression of macrophage cells from G1 to S. J Immunol 174:7226-7233

Luo Y, Isaac BM, Casadevall A, Cox D (2009) Phagocytosis inhibits F-actinenriched membrane protrusions stimulated by fractalkine (CX3CL1) and colony-stimulating factor 1. Infect Immun 77:4487-4495

Ma H, Croudace JE, Lammas DA, May RC (2006) Expulsion of live pathogenic yeast by macrophages. Curr Biol 16:2156-2160

Mansour MK, Latz E, Levitz SM (2006) Cryptococcus neoformans glycoantigens are captured by multiple lectin receptors and presented by dendritic cells. J Immunol 176:3053-3061

McQuiston TJ, Williamson PR (2012) Paradoxical roles of alveolar macrophages in the host response to Cryptococcus neoformans. J Infect Chemother 18:1-9

Means TK, Mylonakis E, Tampakakis E, Colvin RA, Seung E, Puckett L et al (2009) Evolutionarily conserved recognition and innate immunity to fungal pathogens by the scavenger receptors SCARF1 and CD36. J Exp Med 206:637-653

Mednick AJ, Feldmesser M, Rivera J, Casadevall A (2003) Neutropenia alters lung cytokine production in mice and reduces their susceptibility to pulmonary cryptococcosis. Eur J Immunol 33:1744-1753

Miller MF, Mitchell TG (1991) Killing of Cryptococcus neoformans strains by human neutrophils and monocytes. Infect Immun 59:24-28

Nicola AM, Robertson EJ, Albuquerque P, da Derengowski LS, Casadevall A (2011) Nonlytic exocytosis of Cryptococcus neoformans from macrophages occurs in vivo and is influenced by phagosomal $\mathrm{pH}$. MBio 2(4). doi:10.1128/mBio.00167-11

Nicola AM, Albuquerque P, Martinez LR, Dal-Rosso RA, Saylor C, De Jesus M et al (2012) Macrophage autophagy in immunity to Cryptococcus neoformans and Candida albicans. Infect Immun 80:3065-3076

Noverr MC, Cox GM, Perfect JR, Huffnagle GB (2003) Role of PLB1 in pulmonary inflammation and cryptococcal eicosanoid production. Infect Immun 71:1538-1547

O'Meara TR, Holmer SM, Selvig K, Dietrich F, Alspaugh JA (2013) Cryptococcus neoformans Rim101 is associated with cell wall remodeling and evasion of the host immune responses. MBio 4(1). doi:10.1128/mBio.00522-12

Osterholzer JJ, Curtis JL, Polak T, Ames T, Chen GH, McDonald R et al (2008) CCR2 mediates conventional dendritic cell recruitment and the formation of bronchovascular mononuclear cell infiltrates in the lungs of mice infected with Cryptococcus neoformans. J Immunol 181:610-620

Osterholzer JJ, Chen GH, Olszewski MA, Curtis JL, Huffnagle GB, Toews GB (2009a) Accumulation of CD11b + lung dendritic cells in response to fungal infection results from the CCR2-mediated recruitment and differentiation of Ly-6Chigh monocytes. J Immunol 183:8044-8053

Osterholzer JJ, Surana R, Milam JE, Montano GT, Chen GH, Sonstein J et al (2009b) Cryptococcal urease promotes the accumulation of immature dendritic cells and a non-protective $\mathrm{T} 2$ immune response within the lung. Am J Pathol 174:932-943

Pietrella D, Corbucci C, Perito S, Bistoni G, Vecchiarelli A (2005) Mannoproteins from Cryptococcus neoformans promote dendritic cell maturation and activation. Infect Immun 73:820-827

Qu X, Wang A (1991) Purification and antimicrobial activity of human neutrophil defensins. Zhonghua Yi Xue Za Zhi 71:616-619, 642

Qureshi A, Subathra M, Grey A, Schey K, Del Poeta M, Luberto C (2010) Role of sphingomyelin synthase in controlling the antimicrobial activity of neutrophils against Cryptococcus neoformans. PLoS ONE 5:e15587

Qureshi A, Grey A, Rose KL, Schey KL, Del Poeta M (2011) Cryptococcus neoformans modulates extracellular killing by neutrophils. Front Microbiol 2:193

Retini C, Vecchiarelli A, Monari C, Tascini C, Bistoni F, Kozel TR (1996) Capsular polysaccharide of Cryptococcus neoformans induces proinflammatory cytokine release by human neutrophils. Infect Immun 64:2897-2903
Richardson MD, White LJ, McKay IC, Shankland GS (1993) Differential binding of acapsulate and encapsulated strains of Cryptococcus neoformans to human neutrophils. J Med Vet Mycol 31:189-199

Rohatgi S, Gohil S, Kuniholm MH, Schultz H, Dufaud C, Armour KL et al (2013) Fc gamma receptor 3A polymorphism and risk for HIV-associated cryptococcal disease. MBio 4:e00573-e00613

Romani L, Bistoni F, Puccetti P (1997) Initiation of T-helper cell immunity to Candida albicans by IL-12: the role of neutrophils. Chem Immunol 68:110-135

Roseff SA, Levitz SM (1993) Effect of endothelial cells on phagocyte-mediated anticryptococcal activity. Infect Immun 61:3818-3824

Sabiiti W, May RC (2012) Capsule independent uptake of the fungal pathogen Cryptococcus neoformans into brain microvascular endothelial cells. PLoS One 7:e35455

Sabiiti W, Robertson E, Beale MA, Johnston SA, Brouwer AE, Loyse A et al (2014) Efficient phagocytosis and laccase activity affect the outcome of HIVassociated cryptococcosis. J Clin Invest 124:2000-2008

Saha DC, Goldman DL, Shao X, Casadevall A, Husain S, Limaye AP et al (2007) Serologic evidence for reactivation of cryptococcosis in solid-organ transplant recipients. Clin Vaccine Immunol 14:1550-1554

Saylor CA, Dadachova E, Casadevall A (2010) Murine lgG1 and lgG3 isotype switch variants promote phagocytosis of Cryptococcus neoformans through different receptors. J Immunol 184:336-343

Shi M, Li SS, Zheng C, Jones GJ, Kim KS, Zhou H et al (2010) Real-time imaging of trapping and urease-dependent transmigration of Cryptococcus neoformans in mouse brain. J Clin Invest 120:1683-1693

Siegemund S, Alber G (2008) Cryptococcus neoformans activates bone marrow-derived conventional dendritic cells rather than plasmacytoid dendritic cells and down-regulates macrophages. FEMS Immunol Med Microbiol 52:417-427

Stano P, Williams V, Villani M, Cymbalyuk ES, Qureshi A, Huang Y et al (2009) App1: an antiphagocytic protein that binds to complement receptors 3 and 2. J Immunol 182:84-91

Stie J, Fox D (2012) Blood-brain barrier invasion by Cryptococcus neoformans is enhanced by functional interactions with plasmin. Microbiology 158:240-258

Subramaniam KS, Datta K, Quintero E, Manix C, Marks MS, Pirofski LA (2010) The absence of serum IgM enhances the susceptibility of mice to pulmonary challenge with Cryptococcus neoformans. J Immunol 184:5755-5767

Syme RM, Spurrell JC, Amankwah EK, Green FH, Mody CH (2002) Primary dendritic cells phagocytose Cryptococcus neoformans via mannose receptors and Fcgamma receptor $I I$ for presentation to T lymphocytes. Infect Immun 70:5972-5981

Taborda CP, Casadevall A (2002) CR3 (CD11b/CD18) and CR4 (CD11c/CD18) are involved in complement-independent antibody-mediated phagocytosis of Cryptococcus neoformans. Immunity 16:791-802

Tucker SC, Casadevall A (2002) Replication of Cryptococcus neoformans in macrophages is accompanied by phagosomal permeabilization and accumulation of vesicles containing polysaccharide in the cytoplasm. Proc Natl Acad Sci USA 99:3165-3170

Vecchiarelli A, Monari C, Baldelli F, Pietrella D, Retini C, Tascini C et al (1995) Beneficial effect of recombinant human granulocyte colony-stimulating factor on fungicidal activity of polymorphonuclear leukocytes from patients with AIDS. J Infect Dis 171:1448-1454

Vecchiarelli A, Pietrella D, Lupo P, Bistoni F, McFadden DC, Casadevall A (2003) The polysaccharide capsule of Cryptococcus neoformans interferes with human dendritic cell maturation and activation. J Leukoc Biol 74:370-378

Voelz K, Lammas DA, May RC (2009) Cytokine signaling regulates the outcome of intracellular macrophage parasitism by Cryptococcus neoformans. Infect Immun 77:3450-3457

Vu K, Eigenheer RA, Phinney BS, Gelli A (2013) Cryptococcus neoformans promotes its transmigration into the central nervous system by inducing molecular and cellular changes in brain endothelial cells. Infect Immun 81:3139-3147

Vu K, Tham R, Uhrig JP, Thompson GR 3rd, Na Pombejra S, Jamklang M et al (2014) Invasion of the central nervous system by Cryptococcus neoformans requires a secreted fungal metalloprotease. MBio 5:e01101-e01114 
Williams V, Del Poeta M (2011) Role of glucose in the expression of Cryptococcus neoformans antiphagocytic protein 1, App1. Eukaryot Cell 10:293-301

Wozniak KL, Levitz SM (2008) Cryptococcus neoformans enters the endolysosomal pathway of dendritic cells and is killed by lysosomal components. Infect Immun 76:4764-4771
Wozniak KL, Vyas JM, Levitz SM (2006) In vivo role of dendritic cells in a murine model of pulmonary cryptococcosis. Infect Immun 74:3817-3824

Wozniak KL, Kolls JK, Wormley FL Jr (2012) Depletion of neutrophils in a protective model of pulmonary cryptococcosis results in increased IL-17A production by gammadelta T cells. BMC Immunol 13:65

\section{Submit your manuscript to a SpringerOpen ${ }^{\circ}$ journal and benefit from:}

- Convenient online submission

- Rigorous peer review

- Immediate publication on acceptance

- Open access: articles freely available online

- High visibility within the field

- Retaining the copyright to your article

Submit your next manuscript at $\boldsymbol{\wedge}$ springeropen.com 